Arkadiusz Majewski

Uniwersytet Warszawski

\title{
Proces przygotowywania Polski do wstąpienia do NATO jako element transformacji polskiej polityki zagranicznej na przełomie lat 80. i 90. XX wieku.
}

Druga wojna światowa skutkowała stworzeniem nowego, dwubiegunowego ładu międzynarodowego. Obydwa bloki rozpoczęły żmudny proces integracji politycznej i gospodarczej.

W Europie Zachodniej w kwestiach politycznowojskowych istotną rolę odgrywał Pakt Północnoatlantycki (NATO) skupiający zachodnioeuropejskich sojuszników, USA i Kanadę. Po przeciwnej stronie „żelaznej kurtyny” był Układ Warszawski (UW), czyli europejskie państwa socjalistyczne i ZSRR.

Lata 80. przyniosły przełom polityczny. Społeczeństwa państw zależnych od ZSRR, wystąpiły z żądaniami reform, z początku gospodarczych, później politycznych. Zmiany zachodziły także w Polsce. W 1980 roku powstała 
„Solidarność". Ludzie uwierzyli, że mogą wpływać na politykę. Stan wojenny w latach 1981-1983 nie złamał do końca ruchu opozycyjnego. W ślad za polskim przykładem podążyli obywatele Czechosłowacji, Węgier i innych państw „obozu wschodniego". W czerwcu 1989 roku, w częściowo wolnych wyborach do Sejmu i Senatu PRL, komuniści ponieśli prestiżową porażkę, co skutkowało powołaniem koalicyjnego rządu T. Mazowieckiego ${ }^{1}$.

Targany kryzysami wewnętrznymi ZSRR nie potrafił już skutecznie przeciwdziałać zachodzącym zmianom. W nocy z 9 na 10 listopada 1989 upadł „mur berliński”, symbolicznie zakończyła się „zimna wojna”. Europa zmieniła swe oblicze. Większość państw byłego bloku wschodniego, w tym Polska, podjęło działania na rzecz integracji $\mathrm{z}$ zachodnimi strukturami politycznymi: NATO i ówczesnymi Wspólnotami Europejskimi.

Po upadku bloku wschodniego, polski rząd zgłosił swe aspiracje do członkostwa w Sojuszu. Determinantem tych działań było dążenie władz RP do zapewnienia krajowi

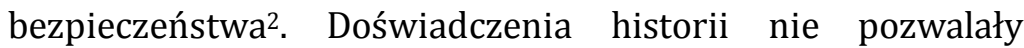
naszemu krajowi na pozostawanie neutralnym. Wejście do NATO włączyłoby Polskę do europejskiego i światowego

112 września Tadeusz Mazowiecki został pierwszym, niekomunistycznym premierem po II wojnie światowej. Podobne wydarzenia miały miejsce na jesieni 1989 roku i w innych stolicach środkowoeuropejskich.

2 R. Zięba, Bezpieczeństwo europejskie a interesy narodowe Polski [w:] K. Wojtaszczyk i J. Niepsuj (red.), NATO a Europa Wschodnia. Rozszerzenie NATO na Wschód - ostatnie wyzwanie europejskie XX wieku, Warszawa 1998, s. 107. 
mechanizmu stabilizacyjnego. Warto więc w tym miejscu przyjrzeć się najważniejszemu zapisowi Traktatu Północnoatlantyckiego, czyli artykułowi nr 5: Strony sq zgodne, że zbrojna napaść na jednq lub kilka z nich $w$ Europie lub Ameryce Północnej będzie uważana za napaść przeciwko nim wszystkim ${ }^{3}$. W artykule stwierdzono, że obrona sojusznika, np. Polski, jest obowiązkiem wszystkich pozostałych członków NATO.

Drugim powodem, dla którego Polska dążyła do członkostwa w NATO była chęć zapewnienia stabilizacji w środkowej części Europy. Przyjęcie do Sojuszu byłych państw socjalistycznych likwidowałoby „szarą strefę" bezpieczeństwa, która wytworzyła się po rozwiązaniu UW4.

Trzeci determinant związany był niewątpliwie z dążeniem do demokratyzacji systemu. Aspirowanie do NATO wymagało bowiem kontynuowania przemian demokratycznych.

Ważnym aspektem była też dwutorowość polskich aspiracji w Europie. Z jednej strony mamy NATO, a z drugiej Unię Europejską. Polska rozpoczynając integrację ze strukturami państw zachodnich nie mogła poprzestać tylko na UE, chociaż była to potężna struktura polityczna, stabilizacyjna i ekonomiczna, nie miała jednak wymiaru militarnego. W skład Unii wchodziło jednak wielu członków NATO i można postawić tezę, że wejście do Sojuszu zwiększało

3 NATO. Vademecum, Warszawa 1999, s. 396.

${ }^{4}$ R. Zięba, op. cit., s. 109. 
wiarygodność negocjacyjną5.

Do Sojuszu należały największe zachodnioeuropejskie państwa. Szczególnego znaczenia nabierało tu członkostwo zjednoczonych, demokratycznych Niemiec, które stały się wkrótce największym europejskim zwolennikiem integracji Polski ze strukturami UE i NATO. Władze Niemiec pragnęły bowiem partnerskich i stabilnych relacji z Polską. Nasz zachodni sąsiad nie chciał też być państwem peryferyjnym NATO i UE. Wejście Polski do NATO dało RFN szansę na zamknięcie frontu wschodniego. Polska miała natomiast dziejową szansę naprawienia stosunków z tym państwem6.

Drugim państwem, z którym Polska chciała mieć specjalne relacje były Stany Zjednoczone, gwarant bezpieczeństwa europejskiego i funkcjonowania NATO. Polskie władze zakładały, że poprzez wejście do NATO państwo stanie się sojusznikiem USA i będzie pod ich ochroną. Byłaby to też wielka szansa dla Wojska Polskiego na modernizację. W pierwszej połowie lat 90. liczono także na pomoc finansową i umorzenie starych długów. Nie bez znaczenia był szacunek jakim otaczano w USA Lecha Wałęsę, a także cały ruch „Solidarności”. Należy też pamiętać o 9-

5 M. Czajkowski, Otwarcie NATO a nowa architektura bezpieczeństwa europejskiego [w:] E. Cziomer (red.), Polska o krok od NATO. Międzynarodowe aspekty przystapienia Polski do sojuszu Północnoatlantyckiego, Kraków 1998, s. 112-113.

6 Z. Kuśmierek, Rozszerzenie NATO - implikacje dla Europy ŚrodkowoWschodniej [w:] K. Wojtaszczyk, J. Niepsuj (red.), op. cit., s. 98; S. Małachowski, Nowa jakość w stosunkach z Niemcami [w:] R. Kuźniar, K. Szczepanik (red.), Polityka zagraniczna RP: 1989-2002, Warszawa 2002, s. 153-159. 
milionowej Polonii amerykańskiej oraz sympatii jaką większość Polaków tradycyjnie darzyła USA7.

Wśród wielu komentarzy pojawiających się na przestrzeni ostatniej dekady opisujących ówczesne nastroje pojawiały się głosy, iż Polska po wejściu do NATO stanie się wasalem USA. Opinia taka wydaje się niezasadna, ponieważ wejście do Sojuszu nie oznaczało oddania suwerenności. Poza tym, warto pamiętać, że priorytetem USA była stabilizacja regionu, a nie podporządkowanie państw.

Dążenia Polski do NATO determinowane były też nieprzewidywalnością sytuacji w Federacji Rosyjskiej. W latach 90. nie wiadomo było w jakim kierunku przebiegać będą zmiany na terenie byłego ZSRR. W Rosji pozostawało ryzyko odejścia od przemian demokratycznych i odbudowywania potęgi $\mathrm{w}$ duchu imperializmu. Niestety historia pokazuje, że zazwyczaj pierwszą ofiarą takiej polityki stawała się Polska. Członkostwo w NATO sprawiało, iż likwidowano tzw. szarą strefę bezpieczeństwa co minimalizowało zagrożenie ze strony Rosji8.

Polemizując ze sceptykami, nie należy też zapominać, że Pakt Północnoatlantycki był swego rodzaju sojuszem cywilizacji zachodniej, kultury europejskiej i euroatlantyckiej, a jego celem była jej obrona9.

Ostatnim powodem przystąpienia Polski do NATO, który

7 J. Stachura, Rola i znaczenie stosunków dwustronnych ze Stanami Zjednoczonymi [w:] R. Kuźniar, K. Szczepanik (red.), op. cit., s. 126-145.

8 R. Zięba, op. cit., s. 108.

9 Ks. J. Krokos, Racja istnienia i kształtu NATO [w:] K. Wojtaszczyk, J. Niepsuj (red.), op. cit., s. 101-105. 


\section{$104 \mid$ Arkadiusz Majewski}

należałoby szczególnie podkreślić to stanowisko Polaków. Co prawda, członkostwo w NATO nigdy nie zostało poddane pod głosowanie w referendum ogólnonarodowym, jednak badania sondażowe wskazywały, że o ile w roku 1992 zwolenników przystąpienia do NATO było tylu co przeciwników (35\%), to już w roku 1993 zwolenników było 57\%. W roku 1996 wskaźnik ten osiągnął 73\% i przez najbliższe lata utrzymał się na zbliżonym poziomie ${ }^{10}$.

Zanim nastąpił przełom roku 1989, polityczna i gospodarcza współpraca międzynarodowa Polski opierać się mogła tylko na państwach bloku wschodniego, w ramach RWPG i UW. Zmiany, które doprowadziły do upadku tych dwóch organizacji wymagały transformacji polityki. Nowe władze, wywodzące się ze środowisk opozycyjnych, przede wszystkim z „Solidarności” nie wypracowały od razu koncepcji wejścia do NATO. Opozycjoniści w latach 80. w swych przemyśleniach na temat polityki zagranicznej wyrażali obawy, że porządek jałtański, będzie jeszcze trwać wiele lat i nie przewidywali możliwości upadku komunizmu. Wysuwanie koncepcji mających zupełnie zmienić tamtą sytuację byłoby więc bezzasadne, a nawet niebezpieczne. Nie wykluczało to jednak formułowania ocen. Bardzo krytycznie odnoszono się do ZSRR stwierdzając, że przyniósł on Polsce niechciany ustrój i okupację. Nie widziano szansy na zmianę stosunków polsko-radzieckich $\mathrm{z}$ poddańczych na partner-

10 R. Kupiecki, Członkostwo w NATO w polskiej polityce zagranicznej [w:] R. Kuźniar, K. Szczepanik (red.), op. cit., s. 110-111. 
skie 11.

Polacy z drugiej strony pamiętali też swoistą zdradę Zachodu w roku 1939, 1944 i 1945, a także brak zainteresowania polskimi problemami w latach późniejszych. Zachodowi zależało bowiem bardziej na stabilizacji wzajemnych stosunków między blokami politycznymi niż obronie polskich interesów ${ }^{12}$. Wielu dziennikarzy, takich jak Stefan Kisielewski czy Stefan Bratkowski deklarowało więc, że jeżeli ZSRR pozwoli na reformy w Polsce, nie musi to od razu oznaczać zerwania współpracy w ramach bloku ${ }^{13}$.

Ideą, która łączyła wszystkich działaczy opozycji była za to chęć współpracy z europejskimi narodami ZSRR, a także sąsiadami z Europy Środkowej14. Przejmując władzę na początku lat 90., opozycjoniści nie byli do tego przygotowani i nie mieli żadnej wspólnej koncepcji i programu.

Odzyskując suwerenność Rzeczpospolita zyskała także swobodę w polityce zagranicznej. Bardzo ważną rolę $w$ tej materii miało powierzenie stanowiska ministra spraw zagranicznych Krzysztofowi Skubiszewskiemu, wybitnemu profesorowi prawa, człowiekowi pragmatycznego kompromisu. Był on znany opozycji jako osoba ciesząca się zaufaniem

11 Kwestię pomysłów na politykę zagraniczną omawia: K. Łabędź, Główne kierunki polityki zagranicznej proponowane przez opozycję polityczna $w$ Polsce w latach osiemdziesiatych XX wieku, [w:] W. Paruch, K. Trembicka (red.), Niepodległość, zależność, suwerenność: problematyka zagraniczna w najnowszej polskiej myśli politycznej, Lublin 2007, s. 83-100.

12 Ibidem, s. 86.

13 Idee Bratkowskiego i Kisielewskiego. Ibidem, s. 88-90.

14 Ibidem, s. 96-97. 
Episkopatu Polski, ale mająca w swym życiorysie „rysę” w postaci należenia do Rady Konsultacyjnej przy gen. Wojciechu Jaruzelskim. Janusz Onyszkiewicz tak mówił o powodach, dla których Skubiszewski został zaakceptowany zarówno przez komunistów jak i opozycję: „Skubiszewski był klasycznym kandydatem kompromisu, bo mogła go zaakceptować także druga strona. Z czasem okazało się, że był to świetny ruch także ze względów merytorycznych. Pierwszy raz zobaczyłem go wakcji na sesji Narodów Zjednoczonych w Nowym Jorku. (...) Profesor zrobił wielkie wrażenie"15. Polityka zagraniczna zyskała więc kierownika, który prowadził dyplomację zgodnie $\mathrm{z}$ polskim interesem stanu, a nie interesem bloku wschodniego.

Wybór Skubiszewskiego okazał się być wielkim zwycięstwem „Solidarności”, ponieważ to ten minister jako pierwszy przecierał drogę Polski do NATO.

Niezwykle istotne było też powierzenie stanowiska prezesa rady ministrów kandydatowi opozycji, Tadeuszowi Mazowieckiemu. Mówił on w swym exposé: „Nasze otwarcie na cała Europę nie oznacza odrzucenie dotychczasowych powiq̨zań i zobowiq̨zań. Jeśli dziś powtarzamy, że nowy rzq̨d, będzie respektował sojusznicze zobowiązania Polski, to nie jest to taktyczny wybieg uspokajajacy. Wypływa to z naszego rozumienia polskiej racji stanu $i$ analizy sytuacji międzynarodowej. Jeśli nadejdzie dzień, w którym bezpieczeństwo europejskie nie będzie wymagało bloków

15 W. Bereś, K. Burnetko, J. Onyszkiewicz, Janusz Onyszkiewicz - ze szczytów do NATO, Warszawa 1999, s. 75. 
wojskowych, pożegnamy się z nimi bez żalu. Wierzymy, że to nastąi"16.

Było to swoiste credo twórców odnowionej w 1989 roku polityki zagranicznej i program, który miał szansę realizacji. Podkreślona została za to chęć współpracy z całą Europą, nie tylko wschodnią. Wyrażony został także strategiczny cel polskiej dyplomacji, czyli otwarcie na Zachód. Oświadczenia tego typu zamykały spekulacje na temat „finlandyzacji” Polski. Zarówno premier, dawna opozycja, jak i szef MSZ byli temu przeciwni ${ }^{17}$. Akcentowano, że Polska nie może deklarować się jako kraj „neutralny” lub „niezaangażowany” ze względu na swoje położenie geograficzne ${ }^{18}$. Najważniejsze dla polskiej dyplomacji w okresie 1989-1991 było zaznaczenie, że jest suwerenna i niezależna ${ }^{19}$.

Truizmem jest stwierdzenie, że nie można uczestniczyć jednocześnie w dwóch zwalczających się sojuszach. Przynależność Polski jednocześnie do NATO i UW byłoby niemożliwe. Konieczne więc stało się wyprowadzenie Polski ze struktur Układu Warszawskiego (UW). Zgodnie z credo polityki zagranicznej przytoczonym powyżej, zarówno premier Mazowiecki, jak i minister Skubiszewski nie składali żądań natychmiastowego opuszczenia przez Polskę UW, co było zresztą w roku 1989 absolutnie niemożliwe. Ważne stanowiska rządowe w sektorze bezpieczeństwa były

\footnotetext{
16 R. Kupiecki, op. cit., s. 100.

17 Ibidem, s. 100.

18 W. Bereś, K. Burnetko, J. Onyszkiewicz, op. cit., s. 79.

19 R. Kuźniar, K. Szczepanik, Wprowadzenie. Podstawy polityki zagranicznej RP [w:] R. Kuźniar, K. Szczepanik, op. cit., s. 28.
} 
opanowane przez komunistów, przede wszystkim resorty siłowe: MON i MSW20. Nie można więc było mówić o wyprowadzeniu wojsk sowieckich z Polski, czy jakichkolwiek reformach UW, ponieważ z polskiej strony nie miał kto podnosić tych kwestii ${ }^{21}$. Nie wyobrażała sobie też tego polska generalicja. Rosjanie uważali też, że skoro wojska radzieckie są w Polsce od wojny, to nie ma powodów, żeby wychodziły. Polska była krajem tranzytowym między NRD i Czechosłowacją, a więc satelitami, gdzie rozpoczynałby się front. Polacy nie byli też w stanie znaleźć sojuszników dla idei rozwiązania UW jesienią 1989 r. W krajach Europy Środkowej opozycja dopiero zaczynała przejmować władzę22.

Wiosną 1990 sytuacja zaczęła się zmieniać. Na Węgrzech i w Czechosłowacji doszło do pierwszych wolnych wyborów, w wyniku których pełnię władzy uzyskali działacze opozycji demokratycznej. W Polsce doszło do rozwiązania PZPR (w styczniu 1990)23. Do MON i MSW zaczęli wchodzić ludzie z otoczenia „Solidarności”, a odchodzili skompromitowani komuniści.

Podobne zmiany miały miejsce $\mathrm{w}$ tajnych służbach i strukturach armii ${ }^{24}$. Wśród dawnych sojuszników ZSRR zaczął się tworzyć solidny front likwidacji UW. W czerwcu

\footnotetext{
20 W. Roszkowski, Najnowsza historia Polski 1980-2002, t. 3, Warszawa 2003, s. 123; W. Bereś, K. Burnetko, J. Onyszkiewicz, op. cit., s. 81.

21 Opinia Lecha Wałęsy z jesieni 1989 została zbita ogólnikami.

W. Bereś, K. Burnetko, J. Onyszkiewicz, op. cit., s. 78.

22 Ibidem, s. 113-114.

23 W. Roszkowski, op. cit., s. 129.

24 W. Bereś, K. Burnetko, J. Onyszkiewicz, op. cit., s. 103-108.
} 
1990 na spotkaniu członków UW, Vaclav Havel, prezydent Czechosłowacji i Jozsef Antall, premier Węgier, przekonali Michaiła Gorbaczowa, że należy rozpocząć dyskusję nad przyszłością sojuszu ${ }^{25}$. Przyjęta wówczas deklaracja głosiła: „Uczestnicy narady opowiadaja się za stworzeniem nowego, ogólnoeuropejskiego systemu bezpieczeństwa, za zjednoczonq Europq pokoju i współpracy. Państwa reprezentowane na naradzie aktywnie uczestniczq $w$ tym dynamicznym procesie idlatego uważaja za konieczne dokonanie przeglądu charakteru i funkcji Układu Warszawskiego.(...) W tej nowej sytuacji państwa reprezentowane na naradzie przystapiq do przeglądu charakteru, funkcji i działalności Układu Warszawskiego, a także do realizacji przekształcenia do $w$ układ suwerennych i równoprawnych państw, zbudowany na demokratycznych podstawach"26.

Deklaracje te pojawiły się w momencie kiedy sowieckie imperium chyliło się ku upadkowi, co ułatwiało zmiany.

Sformułowania „suwerenność” czy „równouprawnienie”, tak rzadkie w oficjalnych dokumentach sowieckich, dały znak dyplomatom polskim, czechosłowackim i węgierskim, że mogą stawiać bardziej radykalne żądania. Gdy politycy sowieccy przedstawili propozycje reformy sojuszu, natrafili na opór ze strony dawnych sojuszników. Polscy dyplomaci już otwarcie zaczęli mówić o potrzebie likwidacji UW. Ich

25 R. Asmus, NATO. Otwarcie drzwi, Warszawa 2002, s. 52.

26 Deklaracja państw - stron Układu Warszawskiego przyjęta na naradzie doradczego komitetu politycznego w Moskwie 7 czerwca 1990 roku [w:] J. Stefanowicz (red.), Polska - NATO. Wprowadzenie i wybór dokumentów 1990-1997, Warszawa 1997, s. 42. 
deklaracje wsparły rządy Czechosłowacji, Węgier a później również Rumunii i Bułgarii27. 15 lutego, na spotkaniu w Wyszehradzie oficjalnie powstał Trójkąt Wyszehradzki. Wydatnie ułatwiło to wzajemną koordynację polityki zagranicznej28. 25 lutego 1991 r. zapadła decyzja o likwidacji 31 marca wojskowych struktur UW przy zachowaniu struktury politycznej29.

Moskwa ponowiła jednak próbę odzyskania przewagi w Europie Centralnej poprzez propozycje umów bilateralnych z byłymi sojusznikami. Propozycje zawierały zakazy wchodzenia do nowych sojuszy i współpracy w ramach wywiadu, powstawania obcych baz wojskowych oraz prawo tranzytu wojsk radzieckich ${ }^{30}$. Rosjanie stworzyli więc niekorzystną atmosferę do jakichkolwiek negocjacji na temat przyszłości Układu Warszawskiego ${ }^{31}$. Narastała też propaganda dążąca do rozwiązania układu. Minister Skubiszewski powiedział w kwietniu 1991, że „układ bez struktur militarnych jest pustą łuską"32. Dawni „towarzysze” ze wschodu spostrzegli, że w kwestii UW, już nie ma czego ratować. Skutkowało to ostateczną decyzją o rozwiązaniu UW z datą 1 lipca 199133. Ceremonia odbyła się w Pradze. Prezydent Havel mówił: „Przed nami wizja Europy

\footnotetext{
27 R. Asmus, op. cit., s. 53.

28 M. Menkiszak, M. A. Piotrowski, Polska polityka wschodnia [w:]

R. Kuźniar, K. Szczepanik, op. cit., s. 216-217.

29 W. Bereś, K. Burnetko, J. Onyszkiewicz, op. cit., s. 118.

30 R. Asmus, op. cit., s. 53; M. Menkiszak, M. A. Piotrowski, op. cit., s. 216.

31 R. Kupiecki, op. cit., s. 102.

32 „Gazeta Wyborcza”, nr 77, 2.04.1991, s. 3.

33 R. Asmus, op. cit., s. 53-54; R. Kupiecki, op. cit., s. 102
} 
demokratycznej, bezpiecznej i zjednoczonej”, a z kolei prezydent Wałęsa: „Bardzo się cieszę, że mamy pogrzeb tej instytucji. Nie lubię jednak pogrzebów i uważam, że w miejsce układu coś musi wyrosnaćc ${ }^{34}$. Adam Michnik komentował w Gazecie Wyborczej: „Koniec Układu Warszawskiego, RWPG to symboliczne przypieczętowanie kresu epoki państw satelickich. Któż z nas uwierzył by jeszcze kilka lat temu, że dożyje tego dnia: finału totalitarnego imperium? Droga do niepodległości stoi otworem ${ }^{35}$.

W tym samym okresie przyjęcie przez kraje Środkowej Europy zasad wolnego rynku spowodowało bezsensowność istnienia Rady Wzajemnej Pomocy Gospodarczej (RWPG) i została ona rozwiązana 28 czerwca 1991 r.36 Droga do intensyfikacji stosunków z państwami i strukturami Zachodu została otwarta.

Aktywne lata 1990 - 1991 przyniosły przełom w relacjach z NATO: zostały nawiązane na płaszczyźnie przyjacielskiej i partnerskiej, zastępując dotychczasową niechęć i wrogość. NATO także dostrzegło potrzebę reform. Polska zrealizowała swój cel rozwiązania UW poprzez wiązanie się układami z NATO. Należy też pamiętać o ciągłej obecności wojsk radzieckich w Polsce. Ich stacjonowanie było hamulcem rozmów o członkostwie w NATO. Doszło jednak do rewolucyjnej zmiany stosunków $\mathrm{z}$ dobrymi widokami na

\footnotetext{
34 „Gazeta Wyborcza”, nr 152, 1.07.1991, s. 1.

35 A. Michnik, Układ Warszawski rozwiązany!, „Gazeta Wyborcza”, nr 77, 1.07.1991, s. 1.

${ }^{36}$ M. Menkiszak, M. A. Piotrowski, op. cit., s. 217.
} 


\section{2 | Arkadiusz Majewski}

przyszłość i pośpiech byłby niewskazany. Skubiszewski mówił, że „każda polityka ma swój czas”. Ustanowienie systematycznych, przyjaznych kontaktów było najważniejszym celem roku 1990 w kwestii akcesji i został on osiągnięty.

Polsce zależało na szybkim wyprowadzeniu armii sowieckiej, utrudniało to bowiem rozmowy akcesyjne do NATO. Wezwanie przez polski rząd naczelnego radzieckiego dowództwa oraz rządu do wycofania swych sił z Polski było wypełnieniem wieloletnich - niewypowiedzianych z powodów politycznych - marzeń społeczeństwa37. Oficjalne negocjacje zostały otwarte 11 grudnia 1990 r., a więc jeszcze, gdy istniały ZSRR i UW. Rosjanie podkreślali jednak: „wyjdziemy gdy będzie trzeba”. Stanowisko to utrudniało rozmowy. Atmosferę podgrzewało podpisanie przez Niemcy i ZSRR układu o wycofaniu wojsk rosyjskich z Niemiec bez udziału Polski. Nasi dyplomaci wspominali później, że delegaci sowieccy nie potrafili przyjąć do wiadomości faktu, iż takie umowy dotyczyły też Polski, ze względu na jej suwerenność i położenie geograficzne, jako kraju tranzytowego dla wycofywanych wojsk. Postawa Moskwy spotkała się z reakcjami władz polskich, które nie wpuściły w styczniu 1991 r. powracających z zachodu wojsk na terytorium RP. Skutkowało to zawarciem kompromisu i Rosjanie zgodzili się na wycofanie jednostek bojowych do 15 listopada 1992,

${ }^{77}$ M. Krogulski, Okupacja w imię sojuszu. Armia Radziecka w Polsce 19561993, Warszawa 2001, s. 155-162. 
pozostałe do końca roku $1993^{38}$.

Kolejnym problemem, który powstał podczas negocjacji była kwestia roszczeń finansowych. Negocjatorzy polscy przedstawili swym partnerom koszty obecności sowieckiej przez ostatnie kilkadziesiąt lat. Nie było żadnych wątpliwości, iż pomijając nawet liczne dziwne wypadki śmierci czy innych przestępstw dokonanych rękami żołnierzy sowieckich w Polsce, to dokonali oni także nieodwracalnych zmian w środowisku naturalnym. Zniszczeniu uległo też wiele dzierżawionych obiektów. Negocjacje zablokowano, ponieważ w odwecie Sowieci przedstawili tzw. „koszty wyzwolenia” Polski spod okupacji hitlerowskiej i działań wojennych na jej terenie na astronomiczną kwotę 38 mld rubli. Dyplomacja polska, dostrzegając patowość sytuacji zaproponowała „opcję zerową”, a więc wzajemną rezygnację z roszczeń. Ostatecznie, do tego rozwiązania przekonał osobiście Borysa Jelcyna prezydent Wałęsa i 22 maja 1992 r. podpisano porozumienie o wycofaniu wojsk rosyjskich z Polski39. Symboliczną datą zakończenia wycofywania jest 17 września 1993. Od 1991 do 1993 roku, kraj opuściło blisko 56 tys. żołnierzy, 599 czołgów, 202 samoloty, 144 helikoptery, oraz jednostki morskie ${ }^{40}$. Pozostał problem zniszczonego mienia wojskowego, zatrutego środowiska naturalnego i nędzy miejscowej ludności, która wcześniej pracowała w radzieckich bazach.

Zmiany zachodzące w państwach byłego bloku

\footnotetext{
38 Ibidem, s. 163-165.

39 Ibidem ,s. 167

40 Ibidem, s. 175.
} 


\section{4 | Arkadiusz Majewski}

wschodniego pozwoliły na otwarcie negocjacji z NATO. W dniach 7-8 listopada 1991 r. w Rzymie odbyło się spotkanie Rady Północnoatlantyckiej. Przyjęto na niej Nową Koncepcję Strategiczną Sojuszu41. Czytamy w niej, że „od 1989 (...) dokonały się gruntowne zmiany polityczne, które radykalnie poprawiły warunki bezpieczeństwa, w jakich Sojusz stara się osiagnąć swe cele. (...) Znikło zmasowane i potencjalne bezpośrednie zagrożenie, które stanowiło główny powód troski Sojuszu $w$ ciagu pierwszych 40 lat jego istnienia. $Z$ drugiej strony, utrzymuje się znaczna niepewność co do przyszłości i zagrożeń dla bezpieczeństwa Sojusz (...). Realizacja Koncepcji będzie więc stale weryfikowana $w$ świetle ewolucji warunków bezpieczeństwa. (...) Dalsze adaptacje tej Koncepcji będq dokonywane w zależności od potrzeb"42.

Członkowie NATO zauważyli, że Sojusz nie może już działać wedle swych starych zasad, ponieważ główny wróg, Układ Warszawski, nie istnieje. Nie zmieniało to jednak ich zdaniem faktu, iż na świecie wciąż było wiele zagrożeń i Sojusz powinien być na nie przygotowany. Punkt 13 mówi bowiem: Interesy bezpieczeństwa Sojuszu moga być również narażone na szwank przez inne zagrożenia o ogólniejszym charakterze, w tym rozprzestrzenianie broni masowej zagłady, zahamowanie dopływu środków o kluczowym znaczeniu oraz

\footnotetext{
41 Nowa koncepcja strategiczna Sojuszu uzgodniona przez szefów państw i rządów uczestniczących w spotkaniu Rady Północnoatlantyckiej uczestniczących w spotkaniu Rady Północnoatlantyckiej, Rzym, 7 - 8 listopada 1991 roku [w:] J. Stefanowicz (red.), op. cit., s. 75-88.

42 Ibidem, s. 75-76.
} 
akcje terrorystyczne i sabotażowe ${ }^{43}$. Sojusz stawiał - zgodnie z omawianą już Deklaracją Londyńską - na dialog i współpracę. W zasadzie powtórzono tezy ze spotkania w Kopenhadze.

Podstawową strategią NATO miało pozostać odstraszanie. Sojusznicy będq utrzymywać siłę militarnq wystarczająca do przekonania jakiegokolwiek potencjalnego agresora, że użycie siły przeciwko terytorium jednego z nich spotka się ze zbiorowq i skuteczna akcja wszystkich, oraz że ryzyko zwiq̨zane ze wszczęciem konfliktu przewyższałoby jakiekolwiek przewidywane korzyści ${ }^{44}$. Oczywiście w praktyce słowa te oznaczały, że Stany Zjednoczone uczynią wszystko co mogą by chronić terytorium całego NATO, a $\mathrm{w}$ razie zagrożenia mogą stosować wszystkie możliwe rozwiązania polityczne i militarne, a nawet szantaż nuklearny i nie cofną się przed użyciem tego środka „ostatecznego rozwiązania”. NATO będzie się bronić, starając się utrzymać wroga na jak najdalej wysuniętych stanowiskach. Gwarantem miała być siła amerykańskiej broni konwencjonalnej i jądrowej. Celem sił NATO - oprócz obrony swoich członków - miało się także stać zapewnianie stabilizacji politycznej i wojskowej w ramach udziału w misjach $0 \mathrm{NZ}^{45}$.

Nowa Koncepcja Strategiczna Sojuszu, była dowodem, iż NATO odrzucało swój zimnowojenny płaszcz. Rozumiano, że przy słabości ONZ i KBWE jest jedyną instytucją mogącą

\footnotetext{
43 Ibidem, s. 76.

44 Ibidem, s. 79-80.

45 Ibidem, s. 81
} 


\section{6 | Arkadiusz Majewski}

reagować na nowe zagrożenia. Podkreślano, iż w tej sytuacji konieczna jest intensyfikacja stosunków $\mathrm{z}$ państwami środkowoeuropejskimi.

Skoro koniunktura zaczęła się powoli zmieniać, 21 grudnia 1991 r. w czasie exposé sejmowego premier Jan Olszewski mógł wypowiedzieć głośniej polskie postulaty: „Jako członek Północnoatlantyckiej Rady Współpracy Polska będzie zacieśniać więź $z$ Sojuszem Północnoatlantyckim. Wobecnej bowiem sytuacji uważamy to za filar bezpieczeństwa europejskiego (...) Rząd będzie dążył do wszechstronnego rozwoju powiqzzań z NATO, jakie umożliwia nasz udział w Północnoatlantyckiej Radzie Współpracy"46.

Najtrudniejszy jest zawsze początek, także w dyplomacji. Dobra wola i wzajemne zrozumienie sprzyjało procesowi zbliżania Polski i innych państw środkowoeuropejskich do NATO. Polacy, tworząc militarnodyplomatyczną „czystą kartę”, przyczynili się do zlikwidowania UW oraz wykazali zainteresowanie wzmacnianiem relacji z NATO. To wszystko zaowocowało po latach żmudnych negocjacji wejściem Polski w 1997 roku do Sojuszu Północnoatlantyckiego.

46 Ibidem, s. 95 